\title{
Corticosteroids Block Binding of Chemotactic Peptide to Its Receptor on Granulocytes and Cause Disaggregation of Granulocyte Aggregates In Vitro
}

\author{
Keith M. Skubitz, Philip R. Craddock, Dale E. Hammerschmidt, and \\ J. Thomas August, Departments of Medicine, and Pharmacology and \\ Experimental Therapeutics, The Johns Hopkins University School of Medicine, \\ Baltimore, Maryland 21205; and Department of Medicine, \\ University of Minnesota Medical School, Minneapolis, Minnesota 55455
}

A в S T R A C T Inhibition of complement-mediated granulocyte aggregation has recently been proposed as a mechanism of action of high-dose corticosteroids in shock states. Postulating that such inhibition might be effected through alteration of receptor function, we examined the effect of methylprednisolone (MP), hydrocortisone (HC), and dexamethasone (DEX) on the extent and kinetics of binding of the synthetic chemotaxin f-methionine-leucine-phenylalanine (FMLP) to its specific receptor on the granulocyte surface. Dosedependent inhibition of binding was observed at corticosteroid concentrations paralleling plasma levels achieved with $30 \mathrm{mg} / \mathrm{kg}$ intravenous bolus therapy; the order of potency was MP $>$ HC $>$ DEX. Receptor number was unaffected by steroid exposure, but the steroids effected a decrease in association rate constant for the FMLP-receptor interaction (35\% of $\mathrm{N}$ for $0.2 \mathrm{mg} / \mathrm{ml} \mathrm{MP}$ ), leading to decreased receptor-ligand affinity. Dissociation kinetics, as examined by coldchase experiments, were unaltered by the corticosteroids. Furthermore, in addition to the inhibition of aggregation previously reported, aggregated granulocytes were found to disaggregate upon addition of corticosteroids; the order of potency was again MP $>\mathrm{HC}>\mathrm{DEX}$, with an MP concentration of $\sim 2-3$ $\mathrm{mg} / \mathrm{ml}$ required to effect complete disaggregation. We conclude that corticosteroids can displace FMLP

This work was presented in part at the Annual Meeting of the American Federation for Clinical Research, San Francisco, Calif. in April 1981, and appears in abstract form in Clin. Res. 29: 278A, 1981.

Dr. Craddock is the recipient of a Research Career Development Award (HL-00479). Dr. Hammerschmidt is the recipient of a Young Investigator Research Award (HL-25043).

Received for publication 7 November 1980 and in revised form 24 February 1981. from the granulocyte surface by slowing association while allowing dissociation to proceed; altered kinetics of receptor-FMLP interaction may explain both the inhibition of granulocyte aggregation and granulocyte disaggregation. If these observations also hold for physiologic stimuli (such as csadesarginine, which behaves similarly with respect to aggregation, inhibition, and disaggregation), such kinetic changes may be important in the clinical effects of very high-dose corticosteroids such as are administered in shock.

\section{INTRODUCTION}

Complement activation may be associated with neutropenia in vivo and has been shown to cause granulocyte (PMN) ${ }^{1}$ aggregation, both in vitro and in vivo $(1,2)$. These phenomena, augmented by the stimulated PMN production of toxic oxygen compounds (3), have been suggested to be important in the pathogenesis of a variety of clinical disorders. They include hemodialysis neutropenia and pulmonary dysfunction ( 1 , $4,5)$, the vasculitis of cholesterol embolization syndrome (6), and the adult respiratory distress syndrome (7-9). Corticosteroids have been shown to blunt the PMN responses to activated complement components (10), and the recent finding that high-dose corticosteroids inhibit granulocyte aggregation in vitro and in vivo $(7,11)$ suggested a possible mechanism for their reported efficacy in the adult respiratory distress syndrome and endotoxic shock (12-18). High-dose cortico-

${ }^{1}$ Abbreviations used in this paper: DEX, dexamethasone sodium phosphate; FMLP, $N$-formyl-methionine-leucinephenylalanine; HBSS, Hanks' balanced salt solution; HC, hydrocortisone sodium succinate; MP, methylprednisolone sodium succinate; PBS, phosphate-buffered saline; PMN, granulocyte. 
steroid therapy has also recently been tried in other diseases such as idiopathic rapidly progressive glomerulonephritis, and further trials are being contemplated $(6,19)$.

Because corticosteroids have been reported to alter surface receptors in some immune adherence assays (20-23), we postulated altered receptor function as a possible mechanism of high-dose corticosteroid effect on granulocyte responses to activated complement components. This hypothesis has been studied using the synthetic chemotaxin $N$-formyl-methionine-leucinephenylalanine (FMLP) as a probe to study the effect of corticosteroids on $\mathrm{PMN}$ receptor function. Although its receptor is distinct from that for complement (C) $5 \mathrm{a}(24)$, FMLP mimics many of the effects of activated complement, including chemotaxis and aggregation of $P M N$, and in vivo induction of neutropenia (25); further, FMLP-induced PMN aggregation is inhibited by the same concentrations of corticosteroids that inhibit C5a-induced aggregation (7). It is unclear from earlier studies whether the blunting effect of corticosteroids upon granulocytes' responses to FMLP and $\mathrm{C5} \mathrm{a}$ is related to an effect upon the receptors for those agents. We therefore examined the effect of corticosteroids on the binding of FMLP to its specific surface receptors on granulocytes.

\section{METHODS}

Cell preparation. Granulocytes were prepared from heparinized human venous blood by the described modification of the method of Boyum $(1,26)$. Cells were suspended at appropriate concentrations in a buffer solution, $\mathrm{pH} 7.2$, consisting of $135 \mathrm{mM} \mathrm{NaCl}, 4.5 \mathrm{mM} \mathrm{KCl}, 1.3 \mathrm{~g} /$ liter dextrose, and $10 \mathrm{mM} \mathrm{N}$-2-hydroxyethylpiperazine- $N$ '2-ethanesulfonic acid (HEPES buffer) or in Hanks' balanced salt solution (HBSS) (M. A. Bioproducts, Bethesda, Md). Differential cell counts performed on Wright's stained cells revealed $>95 \%$ PMN.

Preparation of solutions. Preservative and filler-free hydrocortisone sodium succinate (HC), methylprednisolone sodium succinate (MP) (Upjohn Co., Kalamazoo, Mich.), and dexamethasone sodium phosphate (DEX) (Merck Sharp \& Dohme, West Point, $\mathrm{Pa}$.) were kindly provided by the manufacturers and dissolved in isotonic phosphate-buffered saline (PBS), pH 7.4.

FMLP (Peninsula Laboratories, Inc., San Carlos, Calif.) was dissolved in dimethylsulfoxide at $10 \mathrm{mM}$, diluted in PBS to $1 \mathrm{mM}$, and stored at $-70^{\circ} \mathrm{C}$ until use.

Zymosan-activated plasma was prepared as described (1) by incubating $2 \mathrm{mg}$ zymosan $/ \mathrm{ml}$ of heparinized $(1 \mathrm{U} / \mathrm{ml}$ ) human plasma for $30 \mathrm{~min}$ at $37^{\circ} \mathrm{C}$, followed by removal of zymosan by centrifugation at $10,000 \mathrm{~g}$ for $30 \mathrm{~min}$ at $4^{\circ} \mathrm{C}$. Aliquots were stored at $-70^{\circ} \mathrm{C}$ until use.

Disodium succinate, hydrocortisone-21-phosphate (Sigma Chemical Co., St. Louis, Mo.), 2-deoxy-D-glucose (Aldrich Chemical Co., Milwaukee, Wis.), and [ $\left.{ }^{3} \mathrm{H}\right]$ FMLP (sp act 56.9 Ci/mmol, New England Nuclear, Boston, Mass.) were dissolved in PBS at appropriate concentrations. Deoxyribonuclease (Worthington Biochemical Corp., Freehold, $\mathrm{N}$. J.) was dissolved in $0.1 \mathrm{M} \mathrm{NaCl}(1 \mathrm{mg} / \mathrm{ml})$ and kept at $-70^{\circ} \mathrm{C}$ until use.
Preparation of sonicated cell suspensions. PMN were suspended in HBSS at a concentration of $4 \times 10^{7} / \mathrm{ml}$ and sonicated for $30 \mathrm{~s}$ in a Sonifier cell disruptor (model 350 , Branson Sonic Power Co., Danbury, Conn.). The suspension was then centrifuged at $23,000 \mathrm{~g}$ for $20 \mathrm{~min}$, and the pellet was resuspended in an appropriate volume of HBSS containing $1 \mu \mathrm{g} / \mathrm{ml}$ DNAase. Microscopic examination of the suspensions revealed no intact PMN.

Preparation of glutaraldehyde-fixed cells. Granulocytes were fixed with glutaraldehyde as described (27). Briefly, PMN were suspended at $10^{8}$ cells $/ \mathrm{ml}$ in PBS containing $0.5 \%$ bovine serum albumin (Sigma Chemical Co.) at room temperature and mixed with 1 vol of $0.25 \%$ glutaraldehyde in PBS. After 5 min the reaction was terminated by adding 0.5 vol of PBS containing $5 \%$ bovine serum albumin, and the cells were pelleted and resuspended in the appropriate buffer.

In vivo induction of neutropenia. New Zealand white rabbits were anesthetized with thiopental, and an ipsilateral femoral artery and vein were cannulated (5). FMLP (10 $\mu \mathrm{M}$ in PBS) was infused into the inferior vena cava at a constant rate of $0.5 \mathrm{ml} / \mathrm{min}$ and arterial blood was sampled serially and heparinized $(2 \mathrm{U} / \mathrm{ml})$.

Kinetic analysis of the FMLP receptor interaction. Analysis of equilibrium binding of FMLP receptors was determined as described by Williams et al (24) with minor modifications. Cells were suspended in HBSS at 5-10 $\times 10^{7}$ cells $/ \mathrm{ml} .100 \mu \mathrm{l}$ of cell or sonicated cell suspension was mixed with $17 \mu$ l of corticosteroid or PBS and incubated for $2 \mathrm{~min}$ at room temperature; the cells were then added to $35 \mu \mathrm{l}$ of varying concentrations of $\left[{ }^{3} \mathrm{H}\right] \mathrm{FMLP}$ and $15 \mu \mathrm{l}$ of either PBS or $0.1 \mathrm{mM}$ unlabeled FMLP in a $12 \times 75$-mm polypropylene tube and incubated at $37^{\circ}$ or $4^{\circ} \mathrm{C}$ as indicated for $15 \mathrm{~min}$ with occasional shaking. 135- $\mu$ l portions of each sample were then added to $2 \mathrm{ml}$ of ice cold HBSS, filtered with a Whatman GF/C glass fiber filter (Whatman, Inc., Clifton, N. J.) and washed with $10 \mathrm{ml}$ of $4^{\circ} \mathrm{C}$ HBSS. Filters were air-dried, added to 10 $\mathrm{ml}$ of Aquasol-2 (New England Nuclear), and counted in an LKB scintillation counter (LKB Instruments, Inc., Rockville, Md.). Unless otherwise specified, all data are expressed as specific binding (binding of $\left[{ }^{3} \mathrm{H}\right] \mathrm{FMLP}$ in buffer minus binding of $\left[{ }^{3} \mathrm{H}\right] \mathrm{FMLP}$ in the presence of $10 \mu \mathrm{M}$ unlabeled FMLP). Time-course experiments revealed specific $\left[{ }^{3} \mathrm{H}\right] \mathrm{FMLP}$ binding to whole cells and suspensions of sonicated cells plateaued by $15 \mathrm{~min}$ at both $4^{\circ}$ and $37^{\circ} \mathrm{C}$. Specific $\left[{ }^{3} \mathrm{H}\right] \mathrm{FMLP}$ binding was examined by Sips analysis (28-30), in which the relation $\ln [r /(1-r)]=a \ln c+a \ln$ equilibrium binding constant (Keq) was plotted as $\ln [r(1-r)]$ vs. $\ln c$, where $r$ $=\left(\right.$ concentration of bound $\left.\left[{ }^{3} \mathrm{H}\right] \mathrm{FMLP}\right) /($ total receptor concentration) and $\mathrm{c}=$ free $\left[{ }^{3} \mathrm{H}\right] \mathrm{FMLP}$ concentration. Equilibrium binding data was also analyzed by the method of Scatchard (31) where $\mathrm{r} / \mathrm{c}=K \mathrm{eq}-\mathrm{r}$ Keq.

Dissociation kinetics were determined by incubating $5 \times 10^{7}$ cells $/ \mathrm{ml}$ with receptor saturating concentrations of $\left.{ }^{3} \mathrm{H}\right] \mathrm{FMLP}$ in $\mathrm{HBSS}$ at $37^{\circ} \mathrm{C}$ for $15 \mathrm{~min}$. DNAse (final concentration $1 \mu \mathrm{g} / \mathrm{ml}$ ) and either a large excess of unlabeled FMLP or methylprednisolone (final concentration $5 \mathrm{mg} / \mathrm{ml}$ ) were then added in a small volume at $t=0$, and at varying time intervals, aliquots were taken, filtered through a Whatman GF/C filter, washed with cold HBSS, and the filters were counted as described above. Simultaneous controls were performed in the presence of excess unlabeled FMLP to measure nonspecific binding. Parallel experiments were performed with the addition of sodium azide and 2-deoxyD-glucose in order to block receptor-ligand complex internalization (32). The resulting specific disintegrations per minute (dpm) were calculated, and the concentration of cellbound $\left[{ }^{3} \mathrm{H}\right]$ FMLP was analyzed assuming the relationship: 


$$
\mathrm{RF} \stackrel{\mathbf{k}_{\mathbf{r}}}{\rightarrow} \mathrm{R}+\mathrm{F}
$$

or $d / d t[R F]=-k_{r}[R F]$, where $[R F]=$ the concentration of bound receptor $-\left[{ }^{3} \mathrm{H}\right] \mathrm{FMLP}$ complex. $[\mathrm{R}]=$ the free receptor concentration and $[\mathrm{F}]=$ the free $\left[{ }^{3} \mathrm{H}\right] \mathrm{FMLP}$ concentration (33).

Association kinetics were determined by incubating cells in HBSS in the presence or absence of $0.2 \mathrm{mg} / \mathrm{ml}$ methylprednisolone for $2 \mathrm{~min}$; $\left[{ }^{3} \mathrm{H}\right] \mathrm{FMLP}$ was then added so that the initial $\left[{ }^{3} \mathrm{H}\right] \mathrm{FMLP}$ concentration was at least 10 times the initial concentration of receptor sites (determined by equilibrium binding in the presence of excess $\left.\left[{ }^{3} \mathrm{H}\right] \mathrm{FMLP}\right)$. At varying time intervals samples were removed, filtered, washed, and counted as described. Although simultaneous experiments were performed in the presence of excess unlabeled FMLP to determine nonspecific binding, this correction was insignificant in most association experiments. The resulting disintegrations per minute bound were calculated, and the concentrations of bound and free $\left[{ }^{3} \mathrm{H}\right]$ FMLP were analyzed assuming the relationship:

$$
\mathrm{R}+\mathrm{F} \underset{\mathbf{k}_{\mathrm{r}}}{\stackrel{\mathrm{k}_{\mathrm{f}}}{\rightleftharpoons}} \mathrm{RF} \text { or } \mathrm{d} / \mathrm{dt}[\mathrm{RF}]=\mathrm{k}_{\mathrm{f}}[\mathrm{R}][\mathrm{F}]-\mathrm{k}_{\mathrm{r}}[\mathrm{RF}]
$$

Because $k_{r} \ll K_{r}$ in this system, we may ignore the dissociation reaction during the brief time-course of these experiments. To confirm that the reaction follows second order kinetics, several experiments were also analyzed using the general solution for the second order reaction; $\mathrm{d} / \mathrm{dt}[\ln$ ([Ro] $-[R F]) /\left(\left[F_{0}\right]-[R F]\right)=k_{f}([R o]-[R F])$, where $\left[F_{0}\right]=$ the initial concentration of $\left[{ }^{3} \mathrm{H}\right] \mathrm{FMLP}$ and $[\mathrm{Ro}]=$ the initial receptor concentration (33). When $[\mathrm{Fo}] \gg[\mathrm{Ro}$, we may analyze this reaction as one of pseudo-first order kinetics, that is: $d / d t[R F]=k_{f}[F o][R]$. Integrating, this becomes:

$$
\ln ([R o]-[R F])=\ln \left(\frac{[R o]}{[F o]}\right)-k_{f}[F o] t
$$

or $\mathrm{d} / \mathrm{dt}[\ln ([\mathrm{Ro}]-[\mathrm{RF}])]=-\mathbf{k}_{\mathrm{f}}[\mathrm{Fo}](33)$.

Granulocyte aggregation. Granulocyte aggregation was performed as described (1). $50 \mu \mathrm{l}$ zymosan-activated plasma or FMLP, in PBS, was added to $450 \mu \mathrm{l}$ of a granulocyte suspension $\left(1.1 \times 10^{7} \mathrm{cells} / \mathrm{ml}\right.$ in HBSS $)$, which was being stirred at $700 \mathrm{rpm}$ in a Payton $300 \mathrm{~B}$ aggregometer/recorder system (Payton Associates, Buffalo, N. Y.). After $2 \mathrm{~min}, 50$ $\mu \mathrm{l}$ of corticosteroid solution in PBS was added. The resulting light transmittance was recorded on a stripchart recorder. The state of granulocyte aggregation was also confirmed by light microscopy of aliquots taken from the aggregometer before and after addition of corticosteroid.

\section{RESULTS}

In vivo induction of neutropenia with FMLP. Intravenous infusion of FMLP into rabbits mimicked the effects of similar infusions of activated plasma complement. Following the initiation of a constant infusion of FMLP, there was a prompt neutropenia (as reported with bolus infusion) (25) with the PMN count falling to a mean $20 \%$ of the preinfusion value, and then rising to a preinfusion level by $30 \mathrm{~min}$ despite continued FMLP infusion (Fig. 1). The transience of the neutropenia is attributed to the development of granulocyte refractoriness to repeated stimulation, as we

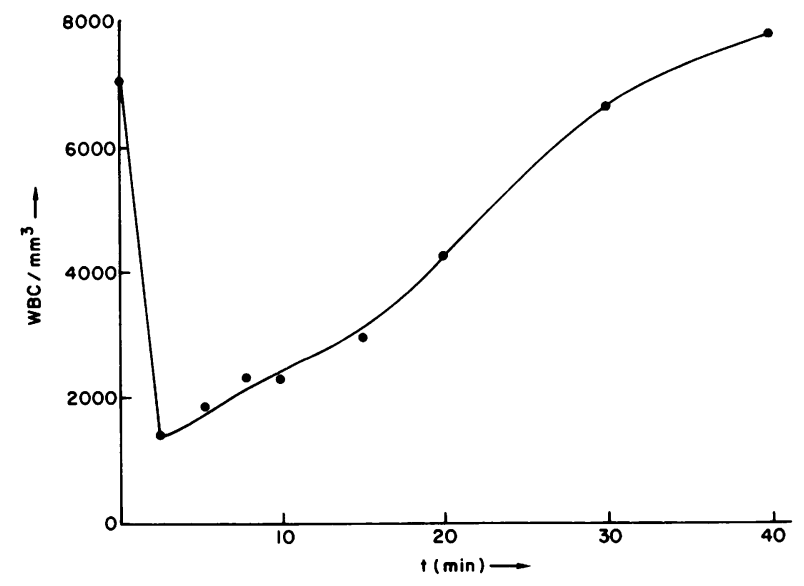

FIGURE 1 Constant infusion of FMLP in rabbits induced transient neutropenia. Peripheral leukocyte count (WBC) (cells per cubic millimeter) of a rabbit vs. time during a constant infusion of $10 \mu \mathrm{M}$ FMLP into the inferior vena cava at a rate of $0.5 \mathrm{ml} / \mathrm{min}$.

have shown in hemodialysis and in vitro with both C5a and FMLP $(34,35)$.

Kinetic analysis of FMLP binding. HC, MP, and DEX inhibited binding of FMLP to the granulocyte surface whereas sodium succinate alone had no effect. Hydrocortisone phosphate blocked $\left[{ }^{3} \mathrm{H}\right] \mathrm{FMLP}$ binding with a potency similar to HC. Inhibition of binding was dose dependent, and the order of potency in receptor blockade (MP $>$ HC $>$ DEX) was the same as that observed in aggregation blockade (7), markedly different from the order of potency observed using classical assays of corticosteroid effect (36) (Fig. 2). Examination of $\left[{ }^{3} \mathrm{H}\right] \mathrm{FMLP}$ binding at varying $\left[{ }^{3} \mathrm{H}\right]-$ FMLP concentrations in the presence and absence of $0.2 \mathrm{mg} / \mathrm{ml} \mathrm{MP}$ did not reveal a decrease in the number of surface FMLP receptors in the presence of MP, although the apparent equilibrium binding constant is clearly reduced by MP (Fig. 3). Sips analysis (28-30) of the binding of $\left[{ }^{3} \mathrm{H}\right] \mathrm{FMLP}$ to granulocytes at $37^{\circ} \mathrm{C}$ in the presence and absence of $0.2 \mathrm{mg} / \mathrm{ml} \mathrm{MP}$ gave a Keq value of $3.4 \times 10^{7} / \mathrm{M}$ in the absence of MP and $1.6 \times 10^{7} / \mathrm{M}$ in the presence of $0.2 \mathrm{mg} / \mathrm{ml} \mathrm{MP} \mathrm{(Fig.}$ 4). Similar experiments were performed at $4^{\circ} \mathrm{C}$ to prevent internalization of peptide-receptor complexes. As reported (37), we found more $\left[{ }^{3} \mathrm{H}\right] \mathrm{FMLP}$ binding at $37^{\circ} \mathrm{C}$ than at $4^{\circ} \mathrm{C}$, likely due to peptide internalization. Scatchard analysis of equilibrium binding of $\left[{ }^{3} \mathrm{H}\right]$ FMLP to granulocytes at $4^{\circ} \mathrm{C}$ in the absence and presence of $0.125 \mathrm{mg} / \mathrm{ml}$ MP gave Keq values of 3.1 $\times 10^{7} / \mathrm{M}$ and $1.1 \times 10^{7} / \mathrm{M}$, respectively, with no change in receptor number. MP also blocked $\left[{ }^{3} \mathrm{H}\right]$ FMLP binding to sonicated neutrophil fragments in a similar manner, and, at high MP concentrations, to glutaraldehyde-fixed PMN as well, further confirming that 


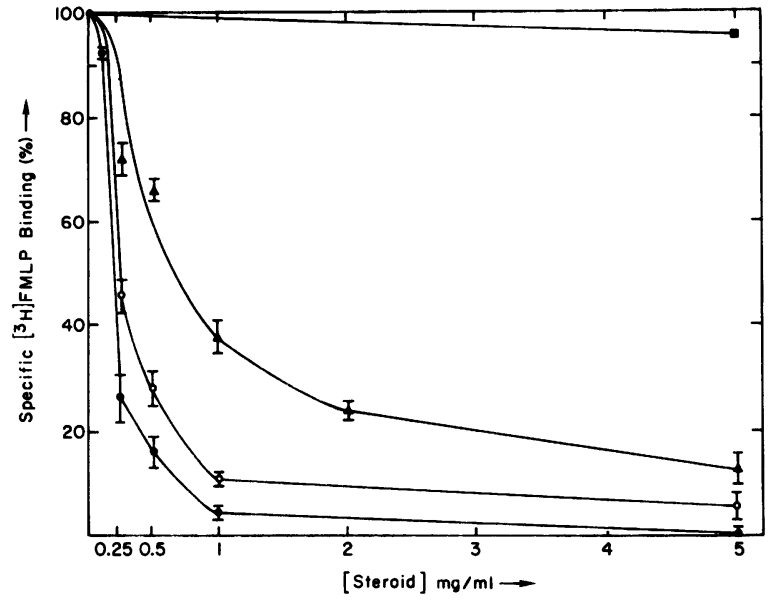

FIGURE 2 Corticosteroids block FMLP binding to specific surface receptors on live human neutrophils. Specific $\left[{ }^{3} \mathrm{H}\right]-$ FMLP binding at equilibrium in the presence of varying concentrations of DEX ( $\triangle)$, HC (O), MP (O), or sodium succinate $(\square)$ at $37^{\circ} \mathrm{C}$, expressed as percent binding observed in the absence of corticosteroid. $\left[{ }^{3} \mathrm{H}\right] \mathrm{FMLP}$ was $32 \mathrm{nM}$. Each point represents the mean $\pm S E M$ of five separate experiments (except sodium succinate which is the mean of two experiments), each of which was performed in triplicate.

blockade could not be attributed to inhibition of internalization.

Dissociation kinetics of FMLP binding. The dissociation rate constant for the peptide-receptor interaction, $k_{r}$, was determined in the presence of excess unlabeled FMLP (Fig. 5). Not all bound $\left[{ }^{3} \mathrm{H}\right]$ FMLP dissociates from the cell, perhaps representing inter-

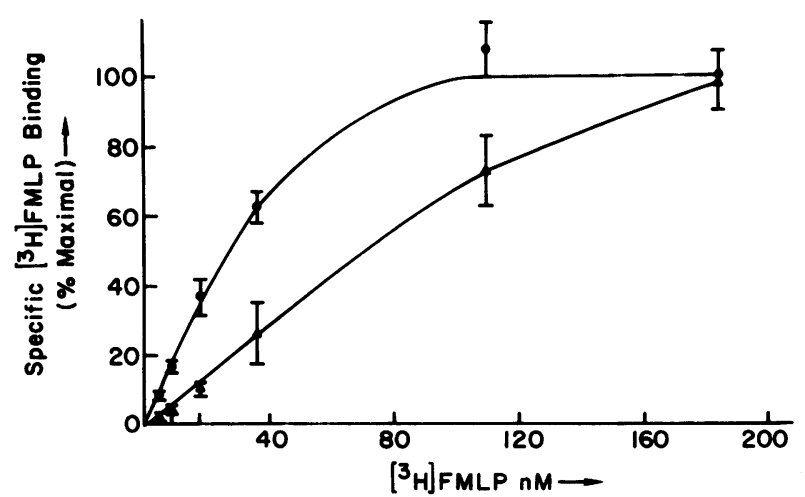

Figure 3 Methylprednisolone decreases the affinity of the FMLP-receptor interaction. Specific $\left[{ }^{3} \mathrm{H}\right] \mathrm{FMLP}$ binding to human neutrophils at varying $\left[{ }^{3} \mathrm{H}\right] \mathrm{FMLP}$ concentrations at $37^{\circ} \mathrm{C}$ in the absence $(O)$ and presence $(\Delta)$ of $0.2 \mathrm{mg} / \mathrm{ml}$ methylprednisolone, expressed as percent binding observed at $180 \mathrm{nM}\left[{ }^{3} \mathrm{H}\right] \mathrm{FMLP}$ in the absence of MP. Each point represents the mean $\pm S E M$ of four separate experiments, each of which was done in triplicate. Calculated $\mathrm{Keq}$ in the absence of MP is $3.1 \times 10^{7}$ and $1.7 \times 10^{7}$ liters $/ \mathrm{m}$ in the presence of 0.2 $\mathrm{mg} / \mathrm{ml} \mathrm{MP}$.

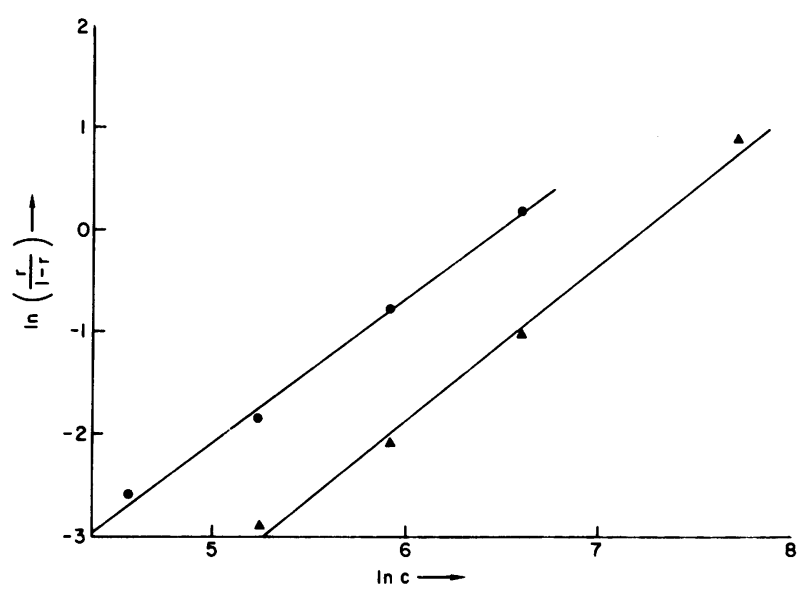

Figure 4 Sips analysis of $\left[{ }^{3} \mathrm{H}\right]$ FMLP-receptor binding data shown in Fig. 4 in the absence $(\boldsymbol{O})$ and presence $(\Delta)$ of 0.2 $\mathrm{mg} / \mathrm{ml} \mathrm{MP}$, respectively. $r=0.998$ for both curves.

nalization of peptide, which is known to occur with an analogue of FMLP (37-40). When the initial portion of the dissociation curve of Fig. 5 is corrected by subtraction of the amount of nondissociating $\left[{ }^{3} \mathrm{H}\right] \mathrm{FMLP}$, $\sim 60 \%$ of the total $\left[{ }^{3} \mathrm{H}\right] \mathrm{FMLP}$ bound before the addition of unlabeled FMLP dissociates with an apparent $k_{r}$ of $1.17 \times 10^{-3} / \mathrm{s}$. The time-course of receptor-ligand dis-

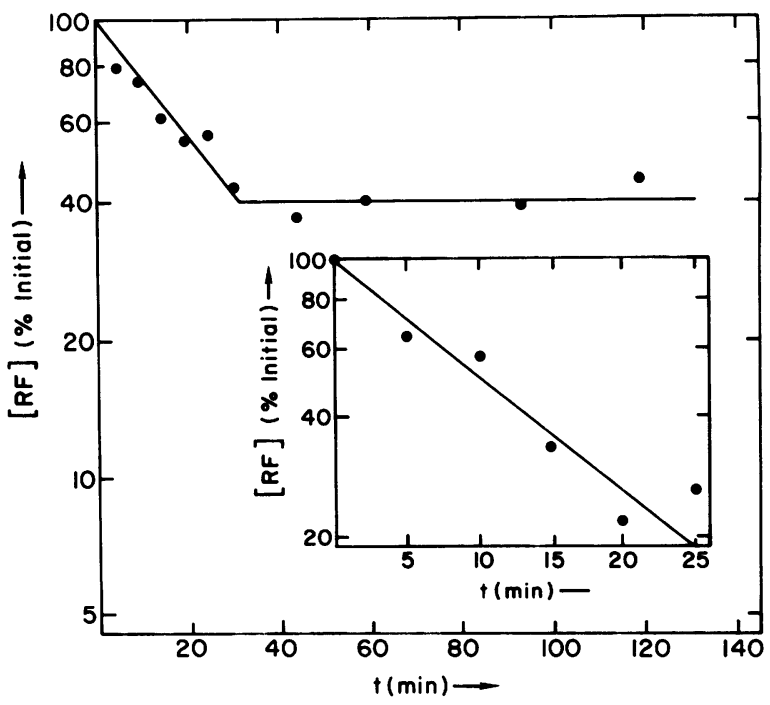

Figure 5 Dissociation kinetics of $\left[{ }^{3} \mathrm{H}\right]$ FMLP-receptor interaction. Dissociation of $\left[{ }^{3} \mathrm{H}\right] \mathrm{FMLP}$ from human neutrophils in the presence of excess unlabeled FMLP plotted as $\ln$ [specific $\left[{ }^{3} \mathrm{H}\right] \mathrm{FMLP}$ binding] (expressed as percent of initial cell-associated radioactivity) vs. time following addition of excess unlabeled FMLP. Each point is the mean of triplicate samples. The insert shows the same data corrected by subtraction of disintegrations per minute observed remaining cell associated at $1 \mathrm{~h}$ (expressed as percent initial cell-associated radioactivity). 
sociation following the addition of excess unlabeled FMLP was the same as that observed following addition of MP to a final concentration of $5 \mathrm{mg} / \mathrm{ml}$ (Fig. 6). The $\mathrm{k}_{\mathrm{r}}$ observed in the presence of excess unlabeled FMLP was $1.32 \pm 0.31(\mathrm{SD}) \times 10^{-3} / \mathrm{s} \quad(n=6)$ and $1.34 \pm 0.26$ $(\mathrm{SD}) \times 10^{-3} / \mathrm{s}(n=4)$ in the presence of $5 \mathrm{mg} / \mathrm{ml} \mathrm{MP}$. Simultaneous addition of $5 \mathrm{mg} / \mathrm{ml} \mathrm{MP}$ and excess unlabeled FMLP produced identical results (not shown). Identical experiments were performed in the presence of $10 \mathrm{mM} \mathrm{NaN}_{3}$ and $10 \mathrm{mM}$ 2-deoxy-D-glucose following a 30-min preincubation of granulocytes in the same concentration of azide and 2-deoxy-D-glucose. This protocol was intended to prevent internalization of receptor-peptide complexes and thus to eliminate the possibility that some of the observed displacement of bound radioactivity was due to intracellular degradation and release of previously internalized peptidereceptor complexes. These experiments again revealed no difference in the rate of displacement of bound radioactivity in the presence of excess unlabeled FMLP as compared with $5 \mathrm{mg} / \mathrm{ml} \mathrm{MP}$. Furthermore, under these conditions $>85 \%$ of the initial cell-bound counts were displaceable with a $\mathrm{k}_{\mathrm{r}}$ of $8.6 \times 10^{-4} / \mathrm{s}$ and 6.4 $\times 10^{-4} / \mathrm{s}$ (mean of two experiments) in the presence of 5 $\mathrm{mg} / \mathrm{ml}$ MP or excess unlabeled FMLP, respectively. We also studied dissociation kinetics at $4^{\circ} \mathrm{C}$, following incubation of neutrophils with receptor saturating concentrations of $\left[{ }^{3} \mathrm{H}\right] \mathrm{FMLP}$ for $20 \mathrm{~min}$ at $4^{\circ} \mathrm{C}$, as a further control for internalization of receptor-bound peptide $(38,39)$. As at $37^{\circ} \mathrm{C}$, not all bound $\left[{ }^{3} \mathrm{H}\right] \mathrm{FMLP}$ dissociates from the cell at the same rate. When dissociation was induced by $5 \mathrm{mg} / \mathrm{ml} \mathrm{MP}, \sim 50 \%$ of the bound

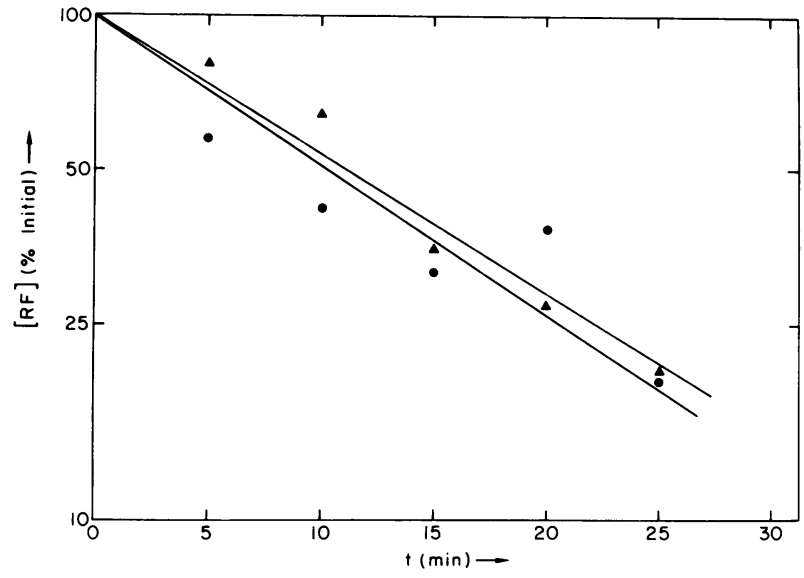

Figure 6 Methylprednisolone does not alter the dissociation rate of $\left[{ }^{3} \mathrm{H}\right] \mathrm{FMLP}$-receptor interaction. Representative plot of In [specific [ ${ }^{3} \mathrm{H}$ ] FMLP binding] (expressed as percent initial binding) corrected for nondissociating counts vs. time, following addition of excess unlabeled FMLP (O) or $5 \mathrm{mg} / \mathrm{ml}$ MP (A). Each point is derived from triplicate samples; $k_{r}$ calculated is $1.05 \times 10^{-3} / \mathrm{s}$ in the presence of excess unlabeled FMLP and $1.14 \pm 10^{-3} / \mathrm{s}$ in the presence of $5 \mathrm{mg} / \mathrm{ml} \mathrm{MP}$. $\left[{ }^{3} \mathrm{H}\right] \mathrm{FMLP}$ dissociated with an apparent $\mathrm{k}_{\mathrm{r}}$ of $3 \times 10^{-2} / \mathrm{s}$ and $>20 \%$ dissociated with an apparent $\mathrm{k}_{\mathrm{r}}$ of 6.5 $\times 10^{-4} / \mathrm{s}$. When dissociation was induced by $10 \mu \mathrm{M}$ unlabeled FMLP, $\sim 40 \%$ of the bound $\left[{ }^{3} \mathrm{H}\right]$ FMLP dissociated with an apparent $\mathrm{k}_{\mathrm{r}}$ of $3 \times 10^{-2} / \mathrm{s}$ and an additional $30 \%$ with an apparent $\mathrm{k}_{\mathrm{r}}$ of $10^{-3} / \mathrm{s}$. Thus, although the observed $k_{r}$ was greater at $4^{\circ} \mathrm{C}$ than $37^{\circ} \mathrm{C}$, perhaps due to peptide internalization, $5 \mathrm{mg} / \mathrm{ml} \mathrm{MP}$ and excess unlabeled FMLP both displaced bound $\left[{ }^{3} \mathrm{H}\right]$ FMLP at similar rates.

Association kinetics of FMLP binding. Analysis of association data as a second order association reaction as described above yielded a straight line, confirming second order kinetics. To simplify the analysis, further experiments were performed under conditions yielding pseudo-first order kinetics in the presence of a 10-fold excess concentration of peptide over receptor (Fig. 7). A single class of forward rate constants is suggested by the linearity of the plot both in the presence and absence of $0.2 \mathrm{mg} / \mathrm{ml} \mathrm{MP}$. The corticosteroid

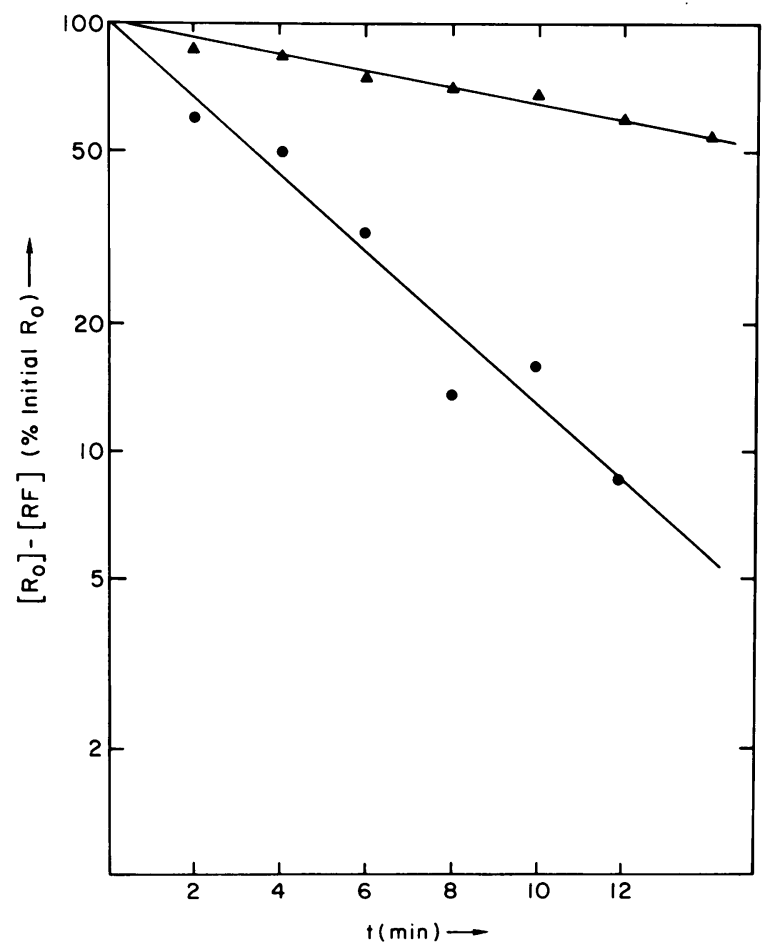

Figure 7 Corticosteroids decrease $k_{f}$ for $\left[{ }^{3} \mathrm{H}\right]$ FMLP-receptor interaction. Association kinetics of a pseudo-first order association reaction of $\left[{ }^{3} \mathrm{H}\right] \mathrm{FMLP}$ with neutrophil surface receptors plotted as $\ln \left(\left[R_{0}\right]-[R F]\right.$ ) (expressed as percent initial [Ro]) vs. time; $[\mathrm{Ro}]=$ initial receptor concentration (determined by equilibrium studies with saturating $\left[{ }^{3} \mathrm{H}\right] \mathrm{FMLP}$ concentration), and $[R F]=$ concentration of $\left[{ }^{3} \mathrm{H}\right]$ FMLP-receptor complexes. Calculated $k_{f}$ in the absence (O) and presence $(\Delta)$ of $0.2 \mathrm{mg} / \mathrm{ml} \mathrm{MP}$ is $1.5 \times 10^{5}$ and $0.32 \times 10^{5}$ liters/ mol per s, respectively. Each point is the mean of triplicate samples. 
markedly decreased the association rate constant from $1.5 \times 10^{5}$ liters $/ \mathrm{mol}$ per s to $0.32 \times 10^{5}$ liters $/ \mathrm{mol}$ per s. These data were also analyzed assuming a $30 \%$ reduction in Ro to estimate the possible error induced by assuming no alteration of receptor number by MP. This calculation yielded a $\mathrm{k}_{\mathrm{f}}$ of $0.48 \times 10^{5}$ liters $/ \mathrm{mol}$ per $\mathrm{s}$, still markedly reduced compared with the absence of MP. Association kinetics in the presence and absence of $0.2 \mathrm{mg} / \mathrm{ml} \mathrm{MP}$ were studied in four and seven separate experiments, respectively, yielding observed $k_{f}$ values of $0.39 \pm 0.21(\mathrm{SD}) \times 10^{5} \mathrm{liters} / \mathrm{mol}$ per s and $1.08 \times .10^{5}$ \pm 0.19 (SD) $\times 10^{5}$ liters $/ \mathrm{mol}$ per s. Similar experiments performed at $4^{\circ} \mathrm{C}$ also revealed values of $k_{f}$ approximately one third lower in the presence of $0.125 \mathrm{mg} / \mathrm{ml}$ MP compared with control. Because the observed $\mathrm{k}_{\mathrm{r}}$ at $4^{\circ} \mathrm{C}$ was larger than that at $37^{\circ} \mathrm{C}$, calculation of accurate $k_{f}$ values was more difficult: $k_{f}$ was $\sim 2.3$ $\times 10^{5}$ and $0.86 \times 10^{5}$ liters $/ \mathrm{mol}$ per $\mathrm{s}$ (means of two experiments) in the absence and presence of 0.125 $\mathrm{mg} / \mathrm{ml} \mathrm{MP}$, respectively.

Disaggregation of granulocyte aggregates by adrenocorticosteroids. Granulocyte aggregation induced by activated complement (Fig. 8) or by FMLP (not shown) proved reversible by corticosteroids. The addition of a saline blank to aggregating PMN produced a dilution effect, followed by continued slow aggregation (second tracing, Fig. 8); DEX (4.5 mg/ml final concentration in cuvette, top tracing) produced similar results. In contrast, however, the addition of $\mathrm{HC}(4.5 \mathrm{mg} / \mathrm{ml}$, third tracing) or MP (3.6 mg/ml, bottom tracing) produced rapid disaggregation after the initial dilution effect. Aggregation and disaggregation inferred from such tracings were confirmed by the microscopic examination of samples taken at appropriate times during the waves. There was no microscopic evidence of

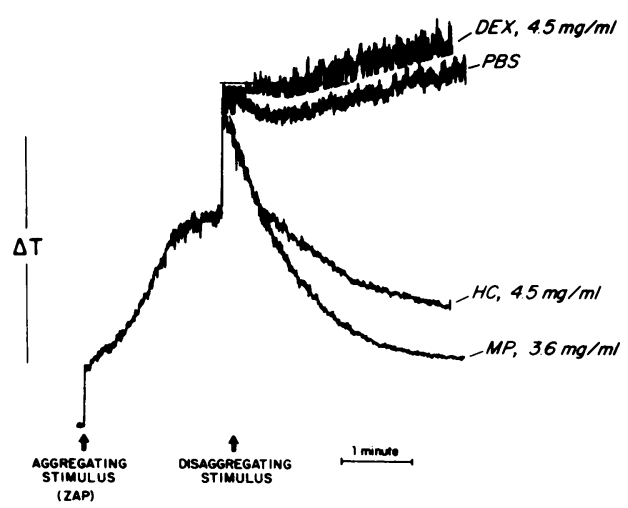

FIgure 8 Corticosteroids disaggregate C5a-induced PMN aggregates. Typical granulocyte aggregation wave showing disaggregation wave following addition of corticosteroids as described in text. Change in light transmittance $(\Delta T)$ is plotted vs. time. As in previous studies, changes in $(\Delta \mathrm{T})$ have been documented to reflect changes in aggregation state. cell lysis during aggregation and subsequent corticosteroid-induced disaggregation, and the cells maintained the ability to exclude trypan blue ( $>95 \%$ viable). As in the case of FMLP binding and corticosteroid blockade of aggregation, corticosteroid-induced disaggregation was dose related, both with respect to corticosteroid and aggregating stimulus. The observed order of potency as inducers of disaggregation was again MP $>\mathrm{HC}>\mathrm{DEX}$, the same as reported for inhibition of aggregation.

\section{DISCUSSION}

Since the introduction of corticosteroids into clinical medicine three decades ago they have been found effective in the treatment of a wide variety of disorders, and much has been written about their mechanism of action. In contrast to the modest doses of these agents used in replacement therapy and in the treatment of chronic immune disorders, very high-dose (30 mg/kg i.v.) corticosteroid therap! has recently been reported to be of benefit in the tre ${ }^{\text {itment }}$ of endotoxic shock and the adult respiratory distress syndrome (1216). It seems likely that the effects of these agents at very high doses might be different from those observed at low doses; in fact, several mechanisms for antiinflammatory action of corticosteroids have been reported, and the concentration ranges at which they are effective differ.

In vivo studies of immune hemolytic anemia suggested corticosteroid treatment in some way altered the interaction between the target erythrocytes and receptors on the surface of the effector reticuloendothelial cell (41-43). Other in vitro and in vivo studies have also implicated an impairment of binding of $\mathrm{C} 3 \mathrm{~b}$ and IgG to their respective receptors on monocyte/ macrophages $(20,21)$, and more recently neutrophils $(22,23)$, to be one effect of supraphysiologic concentrations $(0.05-1.0 \mathrm{mg} / \mathrm{ml})$ of corticosteroids. Recently, using the HL-60 human progranulocytic cell line, it has been demonstrated that $200 \mathrm{nM}$ DEX decreased the number of $\mathrm{Fc}_{\mathrm{c}}$ receptors for IgG expressed on the surface of the myeloid cells without significantly altering the receptor affinity for its ligand (44) and with no gross decrease in protein synthesis. We recently reported that high-dose corticosteroids blocked PMN aggregation in vivo and in vitro (7). We now have examined the effect of corticosteroids on the binding of the synthetic chemotaxin FMLP to its receptor on human granulocytes because previous in vitro and in vivo studies of PMN responses to chemotactic stimuli $(25,35,45,46)$, as well as the in vivo response to FMLP infusion, suggested FMLP is a reasonable model for C5a-induced PMN leukostasis and tissue injury.

The mechanism by which peptide binding is altered 
by corticosteroids was further elucidated by examining the kinetics of interaction of the peptide with its receptor using living whole granulocytes. MP displaced bound radiolabeled FMLP from granulocytes at the same rate as an excess of unlabeled FMLP, suggesting that MP did not alter the rate of dissociation of FMLP from its surface receptor. Because a significant fraction of radiolabel remained cell associated in these experiments, internalization of peptide was a possibility (as has been recently described) (37-40). We therefore sought to prevent $\left[{ }^{3} \mathrm{H}\right] \mathrm{FMLP}$ internalization by performing similar experiments at $4^{\circ} \mathrm{C}$ and by using conditions found to prevent internalization of other receptor ligand complexes in other cell lines $(32,40)$. The observed rates of peptide displacement were similar under both conditions, providing further evidence that MP does not alter the dissociation rate constant. In contrast, when the association rate constant was examined, we found $0.2 \mathrm{mg} / \mathrm{ml} \mathrm{MP}$ decreases $\mathrm{k}_{\mathrm{f}}$ by $\sim 65 \%$.

The mechanism by which corticosteroids alter the receptor-ligand interaction remains unknown. Steroids have been shown to alter membrane fluidity, and the potency of several steroid anesthetics has been shown to correlate with their ability to disorder (increase the molecular freedom of) the hydrocarbon core of lipid bilayers, as measured by electron spin resonance (47). The molecular nature of the FMLP receptor has not been well characterized, but it is quite possible that alterations in membrane fluidity, induced by corticosteroids, could alter surface expression of the receptor or interaction of receptor subunits resulting in a decrease in affinity for the ligand.

We also examined the ability of corticosteroids to cause disaggregation of granulocyte aggregates. We found in vitro corticosteroids cause rapid disaggregation of granulocyte aggregates engendered by zymosanactivated plasma or FMLP in the same concentration range that blocks receptor binding. Furthermore, disaggregation was dose dependent, both with respect to concentration of corticosteroid and to that of aggregation stimulus.

We conclude that high-dose corticosteroids can cause disaggregation of previously aggregated granulocytes as well as block granulocyte aggregation. Furthermore, these same concentrations of corticosteroids alter binding of the synthetic chemotaxin, $\left[{ }^{3} \mathrm{H}\right] \mathrm{FMLP}$, to its specific receptor on the neutrophil surface. This alteration in receptor binding is due primarily to a decrease in the association rate constant for peptide-receptor interaction without significant change in dissociation rate or receptor number. A prominent effect on the FMLP-receptor interaction is observed at MP concentrations of $1 \mathrm{mg} / \mathrm{ml}$ (Fig. 2), a level approximating the plasma concentration immediately after a $30-\mathrm{mg} / \mathrm{kg}$ i.v. bolus, and a substantial effect is seen at even lower concentrations. Furthermore, at lower stimulus concentrations the level of corticosteroid required for effect is less, suggesting that a similar effect might be observed in some clinical situations with even lower corticosteroid concentrations. Receptor alteration may therefore be an important aspect of the effects of highdose corticosteroids on granulocyte aggregation. Similarly, alteration of receptors on other cells for other mediators (for example C5a on endothelial cells) may also contribute to the reported efficacy of high-dose corticosteroids in other clinical syndromes.

\section{ACKNOWLEDGMENTS}

This work was supported in part by the following grants from the National Institutes of Health: 5T-32-CA-09243, AM15730, HL-19725, CA-15627, HL-07062, HL-26218, CA-19471.

\section{REFERENCES}

1. Craddock, P. R., D. E. Hammerschmidt, J. G. White, A. P. Dalmasso, and H. S. Jacob. 1977. Complement (C5a)-induced granulocyte aggregation in vitro: a possible mechanism of complement-mediated leukostasis and leukopenia. J. Clin. Invest. 60: 260-264.

2. Hammerschmidt, D. E., P. D. Harris, H. Wayland, P. R. Craddock, and H. S. Jacob. 1981. Complement-induced granulocyte aggregation in vivo. Am. J. Pathol. 102: 146-150.

3. Sacks, T., C. F. Moldow, P. R. Craddock, T. K. Bowers, and H. S. Jacob. 1978. Oxygen radicals mediate endothelial cell damage by complement-stimulated granulocytes: an in vitro model of immune vascular damage. J. Clin. Invest. 61: 1161-1167.

4. Craddock, P. R., J. Fehr, K. L. Brigham, R. S. Kronenberg, and H. S. Jacob. 1977. Complement and leukocytemediated pulmonary dysfunction in hemodialysis. $N$. Engl. J. Med. 296: 769-774.

5. Craddock, P. R., J. Fehr, A. P. Dalmasso, K. L. Brigham, and H. S. Jacob. 1977. Hemodialysis leukopenia: pulmonary vascular leukostasis resulting from complement activation by dialyzer cellophane membrane. J. Clin. Invest. 59: 879-888.

6. Greenberg, C. S., D. E. Hammerschmidt, P. R. Craddock, and H. S. Jacob. 1979. Atheroma cholesterol activates complement and aggregates granulocytes: possible role in ischemic manifestations of atherosclerosis. Trans. Assoc. Am. Physicians. 92: 130-135.

7. Hammerschmidt, D. E., J. G. White, P. R. Craddock, and H. S. Jacob. 1979. Corticosteroids inhibit complementinduced granulocyte aggregation: a possible mechanism for their efficacy in shock states. J. Clin. Invest. 63: 798803.

8. Hohn, D. C., A. J. Meyers, S. T. Gherini, A. Beckmann, R. E. Markison, and A. M. Chung. 1980. Production of acute pulmonary injury by leukocytes and activated complement. Surgery (St. Louis). 88: 48-58.

9. Hammerschmidt, D. E., L. J. Weaver, L. D. Hudson, P. R. Craddock, and H. S. Jacob. 1980. Association of complement activation and elevated plasma-C5a with adult respiratory distress syndrome. Lancet. I: 947-949.

10. Sneiderman, C. A., and J. W. Wilson. 1975. Effects of corticosteroids on complement and the neutrophilic polymorphonuclear leukocyte. Transplant. Proc. 7: 4147.

11. O'Flaherty, J. T., P. R. Craddock, and H. S. Jacob. 1977. 
Mechanism of anti-complementary activity of corticosteroids in vivo: possible relevance in endotoxin shock. Proc. Soc. Exp. Biol. Med. 154: 206-209.

12. White, G. L., L. T. Archer, B. K. Beller, and L. B. Hinshaw. 1978. Increased survival with methylprednisolone treatment in canine endotoxin shock. J. Surg. Res. 25: 357-364.

13. Schumer, W. 1976. Steroids in the treatment of clinical septic shock. Ann. Surg. 184: 333-341.

14. Fine, J., C. Palmerio, and S. Rutenberg. 1968. New developments in therapy of refractory traumatic shock. Arch. Surg. 96: 163-175.

15. Kusajima, K., S. D. Wax, and W. R. Webb. 1973. Effects of methylprednisolone on pulmonary microcirculation. Surg. Gynecol. Obstet. 139: 1-5.

16. Sladen, A. 1976. Methylprednisolone. Pharmacologic doses in shock lung syndrome. J. Thoracic Cardiovasc. Surg. 71: 800-806.

17. Lillehei, R. C., R. H. Dietzman, G. J. Motsay, C. D. Beckman, L. H. Romero, and C. H. Shatney. 1974. Growth of the concept of shock and review of present knowledge. In Steroids and Shock, T. M. Glenn, editor. University Park Press, Baltimore, Md. 377-413.

18. Wilson, J. W. 1972. Treatment or prevention of pulmonary cellular damage with pharmacologic doses of corticosteroids. Surg. Gynecol. Obstet. 134: 675-681.

19. Oredugba, O., D. C. Mazumdar, J. S. Meyer, and $\mathbf{H}$. Lubowitz. 1980. Pulse methylprednisolone therapy in idiopathic, rapidly progressive glomerulonephritis. Ann. Intern. Med. 92: 504-506.

20. Schreiber, A. D., J. Parsons, P. McDermott, and R. A. Cooper. 1975. Effect of corticosteroids on the human monocyte IgG and complement receptors. J. Clin. Invest. 56: 1189-1197.

21. Hunninghake, G. W., and A. S. Fauci. 1977. Immunologic reactivity of the lung. III. Effects of corticosteroids on alveolar macrophage cytotoxic effector cell function. J. Immunol. 118: 146-150.

22. Tolone, G., L. Bonasera, and R. Sajeva. 1979. Effects of hydrocortisone on binding of IgG or C3b-coated erythrocytes to human monocytes and polymorphonuclear leukocytes. J. Pharm. Pharmacol. 31: 563-564.

23. Klempner, M. S., and J. I. Gallin. 1978. Inhibition of neutrophil Fc receptor function by corticosteroids. Clin. Exp. Immunol. 34: 137-142.

24. Williams, L. T., R. Synderman, M. C. Pike, and R. J. Lefkowitz. 1977. Specific receptor sites for chemotactic peptides on human polymorphonuclear leukocytes. Proc. Natl. Acad. Sci. U. S. A. 74: 1204-1208.

25. O'Flaherty, J. T., H. J. Showell, and P. A. Ward. 1977. Neutropenia induced by the systemic infusion of chemotactic factors. J. Immunol. 118: 1586-1589.

26. Böyum, A. 1968. Isolation of mononuclear cells and granulocytes from blood. Isolation of mononuclear cells by one centrifugation, and of granulocytes by combining centrifugation and sedimentation at $1 \mathrm{~g}$. Scand. J. Clin. Lab. Invest. Suppl. 97. 21: 77-89.

27. Williams, A. F., G. Galfre, and C. Milstein. 1977. Analysis of cell surfaces by xenogeneic myeloma-hybrid antibodies: differentiation antigens of rat lymphocytes. Cell. 12: $663-673$.

28. Karush, F. 1956. The interaction of purified antibody with optically isomeric haptens. J. Am. Chem. Soc. 78: 5519-5526.

29. Nisonoff, A., and D. Pressman. 1958. Heterogeneity and average combining constants of antibodies from individual rabbits. J. Immunol. 80: 417-428.

30. Eisen, H. 1964. Equilibrium dialysis for measurement of antibody-hapten affinities. Methods Med. Res. 10: 106-114.

31. Scatchard, G. 1949. The attraction of proteins for small molecules. Ann. N. Y. Acad. Sci. 51: 660-672.

32. Schlessinger, J., Y. Shechter, M. C. Willingham, and I. Pastan. 1978. Direct visualization of binding, aggregation, and internalization of insulin and epidermal growth factor on living fibroblastic cells. Proc. Natl. Acad. Sci. U. S. A. 75: 2659-2663.

33. Moore, W. J. 1972. In Physical Chemistry. Prentice-Hall, Inc., Englewood Cliffs, N. J. 329-344.

34. Skubitz, K. M., and P. R. Craddock. 1978. The transience of hemodialysis neutropenia results from selective refractoriness of granulocytes to repeated C5a-induced aggregation. Blood. 52: 128. (Abstr.)

35. Skubitz, K. M., and P. R. Craddock. 1981. The reversal of hemodialysis granulocytopenia and pulmonary leukostasis: a clinical example of selective down-regulation of granulocyte responses to ${ }^{\mathrm{csa}}$ desarg. J. Clin. Invest. 67 . 1383-1391.

36. Hirata, F., E. Schiffmann, K. Venkatasubramanin, D. Salomon, and J. Axelrod. 1980. A phospholipase $\mathrm{A}_{2}$ inhibitory protein in rabbit neutrophils induced by glucocorticoids. Proc. Natl. Acad. Sci. U. S. A. 77: 25332536.

37. Vitkauskas, G., H. J. Showell, and E. L. Becker. 1980. Specific binding of synthetic chemotactic peptides to rabbit peritoneal neutrophils: effects on dissociability of bound peptide, receptor activity and subsequent biologic responsiveness (deactivation). Molecular Immunology. 17: 171-180.

38. Niedel, J. E., I. Kahane, and P. Cuatrecasas. 1979 Receptor-mediated internalization of fluorescent chemotactic peptide by human neutrophils. Science (Wash. D. C.). 205: 1412-1414.

39. Niedel, J., S. Wilkinson, and P. Cuatrecasas. 1979. Receptor-mediated uptake and degradation of $\left.{ }^{[25} \mathrm{I}\right]-$ chemotactic peptide by human neutrophils. J. Biol. Chem. 254: 10700-10706.

40. Sullivan, S. J., and S. H. Zigmond. 1980. Chemotactic peptide receptor modulation in polymorphonuclear leukocytes. J. Cell Biol. 85: 703-711.

41. Atkinson, J. P., and M. M. Frank. 1974. Complementindependent clearance of IgG-sensitized erythrocytes: inhibition by cortisone. Blood. 44: 629-637.

42. Atkinson, J. P., A. D. Schreiber, and M. M. Frank. 1973. Effects of corticosteroids and splenectomy on the immune clearance and destruction of erythrocytes. J. Clin. Invest. 52: 1509-1517.

43. Schreiber, A. D., B. S. Herskovitz, and M. Goldwein. 1977. Low-titer cold-hemagglutinin disease (mechanism of hemolysis and response to corticosteroids). N. Engl. J. Med. 296: 1490-1494.

44. Crabtree, G. R., A. Munck, and K. A. Smith. 1979. Glucocorticoids inhibit expression of Fc receptors on the human granulocyte cell line HL-60. Nature (Lond.). 279: $338-339$.

45. Hammerschmidt, D. E., P. R. Craddock, J. McCullough, R. S. Kronenberg, A. P. Dalmasso, and H. S. Jacob. 1978. Complement activation and pulmonary leukostasis during nylon fiber filtration leukapheresis. Blood. 51: 721-730.

46. O'Flaherty, J. T., D. L. Kreutzer, H. J. Showell, G. Vitkauskas, E. L. Becker, and P. A. Ward. 1979. Selective neutrophil desensitization to chemotactic factors. J. Cell Biol. 80: 564-572.

47. Lawrence, D. K., and E. W. Gill. 1975. Structurally specific effects of some steroid anesthetics on spinlabeled liposomes. Mol. Pharmacol. 11: 280-286. 